\title{
Investigation on Combustion Characteristics of Malaysian Domestic Wastewater Sludge
}

\author{
Suhaimi Hassan, Safuan Zakaria, Michael Lo Yin Kai and M.Faizairi M.Nor \\ Department of Mechanical Engineering, University of Technology PETRONAS (UTP), Perak, Malaysia
}

Correspondence Author: Suhaimi Hassan, Department of Mechanical Engineering, University of Technology PETRONAS, 32610 Seri Iskandar, Perak, Malaysia

Received date: 11 June 2019, Accepted date: 28 July 2019, Online date: 8 August 2019

Copyright: (c) 2019 Suhaimi Hassan, et al. This is an open-access article distributed under the terms of the Creative Commons Attribution License, which permits unrestricted use, distribution, and reproduction in any medium, provided the original author and source are credited.

\begin{abstract}
Domestic wastewater sludge (DWS) is a great source of biomass energy as it is abundant and contain high organic materials to be converted to fuel. This research is aimed to study the combustion characteristics of dried Malaysian DWS through proximate analysis, ultimate analysis and bomb calorimetry, and thermal behaviour of DWS through combustion by thermogravimetric analysis (TGA) at different heating rates of 10 $\mathrm{K} / \mathrm{min}, 20 \mathrm{~K} / \mathrm{min}$ and $30 \mathrm{~K} / \mathrm{min}$ under constant flowrate of oxygen $(20 \mathrm{~mL} / \mathrm{min})$ from room temperature to $850^{\circ} \mathrm{C}$. This research will evaluate potential of Malaysian DWS as biomass fuel by comparing its characteristic with other DWS and selected biomass. DWS sourced from UTP Sewage Treatment Plant is used for the study. From proximate analysis, the physical characteristic of UTP DWS has moisture content of $10.61 \mathrm{wt} \%$, volatile matter of $39.84 \mathrm{wt} \%$, fixed carbon of $18.61 \mathrm{wt} \%$ and ash content of $30.94 \mathrm{wt} \%$. From ultimate analysis, the chemical characteristic of UTP DWS has carbon of $36.06 \mathrm{wt} \%$, hydrogen of $5.28 \mathrm{wt} \%$, nitrogen of $10.48 \mathrm{wt} \%$ and sulphur of $5.04 \mathrm{wt} \%$. UTP DWS has calorific value of $13 \mathrm{MJ} / \mathrm{kg}$. The characteristics of UTP DWS are comparable with other DWS except for nitrogen and sulphur content. The thermal profiles are presented in thermogravimetric (TG) curve and derivative thermogravimetric (dTG) curve, the curves depicted 3 stages of combustion process where combustion is most reactive in combustion of fixed carbon. The combustion reactivity is highest at heating rates of $30 \mathrm{~K} / \mathrm{min}$. The ignition temperature of UTP DWS is at $230^{\circ} \mathrm{C}$ and burnout temperature at $600^{\circ} \mathrm{C}$. The burning time decreased significantly when heating rates increased.
\end{abstract}

Keywords: domestic wastewater sludge; combustion characteristics; thermal behaviour; TGA

\section{INTRODUCTION}

Energy is typically categorised into renewable energy and non-renewable energy. According to International Energy Agency [1] projects that global energy demand will grow by $30 \%$ in 2040 . The conventional non-renewable energy played a crucial role in climate change and global warming. Renewable energy is posed as the solution to address growing energy demand and dampen the irreversible climate change. Renewable energy such as biomass energy is increasingly preferred for its ability to convert waste into energy. Biomass fuels are organic materials that can be combusted to generate power. Domestic wastewater sludge (DWS) is an emerging source of biomass fuel as it has a high amount of organic matter.

Ujang and Henze [2] projected by 2020, Malaysia will be generating 7.2 million cubic metres of wastewater sludge. The sludges are taking up more footprint in the landfills every year. The wastewater treatment process is power-intensive due to and it would be energy and cost-effective if treatment plants are able to generate and recover energy by utilising DWS as biomass fuel source. There are limited studies done on Malaysian DWS as of now that evaluate the potential of Malaysian DWS as fuel source of biomass energy.

Wastewater is mostly made up of water, dissolved solids and suspended solids; it is used to carry unwanted waste for treatment. Domestic wastewater is used to carry waste from ordinary day-to-day activities from domestic premises such as human waste, or food waste Composition of domestic wastewater varies from region to region depending on activity type of the area [3].

Wastewater in Malaysia is mostly managed by Indah Water Konsortium (IWK). The water treatment processes employed by IWK consist of preliminary treatment, primary treatment and secondary treatment.

In preliminary treatment, coarse materials such as rubbish, plastics and rocks are screened and removed; grease and oil are trapped and removed. In primary treatment, wastewater has flowed into clarifiers for the sedimentation process. Solids are settled on the bottom of the tank and floatable materials on the surface of the clarifier are skimmed off. In secondary treatment, wastewater sludge is biologically treated to accelerate its aerobic degradation of organic materials. The wastewater sludge from secondary treatment is treated and dewatered, then transported to landfills for disposal.

According to Shizas and Bagley [4], primary sludge has the highest energy content among raw wastewater, secondary sludge and anaerobically digested sludge.

To better understand the characteristics of wastewater sludge and its expected value, studies on characteristics of domestic wastewater sludge from various region and industrial wastewater sludge are reviewed [5-10].

Through proximate analysis, physical characteristics such as moisture content (M), volatile matter (VM), fixed carbon (FC) and ash (A) of the sample tested are determined through weight loss in different degradation process at diverse temperature range. Typical physical characteristics of DWS by weight are 10\% M, $50 \% \mathrm{VM}, 10 \% \mathrm{FC}$ and 30\% A. Industrial wastewater sludges have slightly higher VM and lower A than DWS. 
In ultimate analysis, the chemical characteristic of sample tested is identified. Elements such as carbon (C), hydrogen (H), nitrogen $(\mathrm{N})$ and sulphur $(\mathrm{S})$ are identified in the sample tested and their composition in percentage is determined. Typical chemical characteristics of DWS by weightage are $35 \% \mathrm{C}, 5 \% \mathrm{H}, 5 \% \mathrm{~N}$, $1 \% \mathrm{~S}$ and $54 \%$ other elements (mostly oxygen and ash). Industrial wastewater sludges have higher $\mathrm{C}$ weightage.

In bomb calorimetry, the calorific value of the sample tested is determined through fuel combustion in bomb calorimeter under standard conditions. Typical calorific value of DWS is $14 \mathrm{MJ} / \mathrm{kg}$ whereas calorific values of industrial wastewater sludges are higher than DWS.

Thermogravimetric analysis (TGA) are used to analyse the mass fluctuations of the sample tested when combusted. It records and evaluates the changes of samples' mass with different atmosphere, gas flow rate or heating rate.

TGA is used on DWS to determine its combustion profiles and thermal characteristics. The results of TGA are represented in the thermogravimetric curve (TG) and derivative thermogravimetric curve (dTG). TG curve depicts weight loss against temperature and dTG curve depicts rate of weight loss against temperature.

Thermal behaviour of DWS can be interpreted from TG and dTG curves through identifying temperature ranges of different degradation stage and their degradation reactivity at the peak temperature of the degradation stage. Combustion performance of DWS can also be interpreted from TG and dTG curves by identifying the ignition temperature, peak temperature and burnout temperature across the combustion process in TGA.

\section{Objectives}

This project is aimed to study combustion characteristics of Malaysian DWS through proximate analysis, ultimate analysis and bomb calorimetry. This project will investigate the thermal behaviour of DWS with different heating rates through thermogravimetric analysis (TGA). The outcome of the analyses on DWS will be evaluated for its potential to be biomass solid fuel by comparing the characteristics of DWS with other related DWS studies and selected biomass.

This study will only source DWS from Malaysian wastewater treatment plant that treats wastewater from the residential or institutional region. The DWS will be thermally dried and sieved into $1 \mathrm{~mm}$ size before used for analyses. The thermal behaviour of DWS will only be investigated through combustion by TGA at different heating rates.

\section{MATERIALS AND METHODS}

DWS for the study was obtained from Universiti Teknologi PETRONAS Sewage Treatment Plant (UTP STP) in Perak, Malaysia. The primary sludge was sampled from the clarifier tank return to the aeration tank. The initial moisture content is removed through direct exposure to sunlight for 6 hours per day for 5 days. Due to high moisture content in the atmosphere, the sample is further dried using thermal oven at $105^{\circ} \mathrm{C}$ for 24 hours in day-6 [6]. The final moisture content of the DWS is $14 \%$. The moisture content of the sample is reduced to less than $30 \%$ or as low as possible the reason due to of high moisture content samples has lower combustion efficiency compared to low moisture content samples (Werther and Ogada, 1999). The sludge sample was then sieved through $1 \mathrm{~mm}$ sieve and stored in airtight container to avoid contamination and reabsorption of moisture from the atmosphere.

\subsection{Proximate Analysis}

The proximate analysis was conducted using SETARAM LABSYS Evo TGA analyser. Proximate analysis was conducted to extricate physical characteristics such as moisture content (M), volatile matter (VM), fixed carbon (FC) and ash (A).

Three $10 \mathrm{mg}$ samples undergone proximate analysis under inert and oxidative atmosphere with a gas flow rate of $20 \mathrm{~mL} / \mathrm{min}$ and heating rate of $10 \mathrm{~K} / \mathrm{min}$.

The samples in alumina crucible is placed in TGA furnace and heated from room temperature to $100^{\circ} \mathrm{C}$ under $\mathrm{N} 2$ and afterwards undergo isothermal step at $100^{\circ} \mathrm{C}$ for 10 minutes under $\mathrm{N} 2$ to evaluate the weight loss percentage of the drying process to evaluate the of moisture content of the samples. The temperature is then increased from $100^{\circ} \mathrm{C}$ to $600^{\circ} \mathrm{C}$ then undergo isothermal step at $600^{\circ} \mathrm{C}$ for 15 minutes under $\mathrm{N} 2$ and another 15 minutes isothermal step under $\mathrm{O} 2$ to allow for samples' weight loss associated with volatile matter. The furnace temperature is then increased from $600^{\circ} \mathrm{C}$ to $850^{\circ} \mathrm{C}$ under $\mathrm{O} 2$ to allow char oxidation combustion. The weight loss is attributed to fixed carbon. The remaining residue obtained from the experiment is ash content from incombustible char.

\subsection{Ultimate Analysis}

Five $2 \mathrm{mg}$ DWS samples undergone ultimate analysis in accordance to ASTM D5373.

Chemical characteristics of DWS were identified through ultimate analysis using Elementar's vario MICRO cube elemental analyser. Elements such as carbon $(\mathrm{C})$, hydrogen $(\mathrm{H})$, nitrogen $(\mathrm{N})$ and sulphur $(\mathrm{S})$ were identified in the sample tested and their composition in percentage was determined.

\subsection{Bomb Calorimetry}

Three $1 \mathrm{~g}$ DWS samples undergone bomb calorimetry in accordance to ASTM D2015.

The calorific value of DWS was determined using Bomb Calorimeter IKA Bomb Calorimeter C5000.

\subsection{Thermogravimetric Analysis (TGA)}

Thermogravimetric analysis was conducted using SETARAM LABSYS Evo TGA analyser. TGA is conducted to study the thermal behaviour and TGA characteristic of UTP DWS.

Three $10 \mathrm{mg}$ samples undergone TGA under an oxidative atmosphere with gas flow rate of $20 \mathrm{~mL} / \mathrm{min}$. The experiments were repeated at a heating rate of 10 $\mathrm{K} / \mathrm{min}, 20 \mathrm{~K} / \mathrm{min}$ and $30 \mathrm{~K} / \mathrm{min}$.

The samples in alumina crucible are placed in TGA furnace and heated from room temperature to $100^{\circ} \mathrm{C}$ under $\mathrm{O} 2$ and afterwards undergo isothermal step at $100^{\circ} \mathrm{C}$ for 10 minutes under $\mathrm{O} 2$. The temperature is then increased from $100^{\circ} \mathrm{C}$ to $600^{\circ} \mathrm{C}$ then undergo isothermal level at $600^{\circ} \mathrm{C}$ for 30 minutes isothermal step under $\mathrm{O} 2$. The furnace temperature is then increased from $600^{\circ} \mathrm{C}$ to $850^{\circ} \mathrm{C}$ under $\mathrm{O} 2$. The graph of weight percentage loss against temperature (TG curve) and graph derivative weight percentage loss against temperature (dTG curves) were recorded throughout TGA by Pyris Software.

\section{RESULTS AND DISCUSSIONS}

In this study, the characteristics of UTP DWS are identified through proximate analysis, ultimate analysis and bomb calorimetry. Comparison on the characteristics of UTP DWS was made between different DWS and biomass.

The thermal behavior of UTP DWS are investigated through TGA by combustion of UTP DWS at heating rates of $10 \mathrm{~K} / \mathrm{min}, 20 \mathrm{~K} / \mathrm{min}$ and $30 \mathrm{~K} / \mathrm{min}$.

\subsection{Proximate Analysis}

The physical characteristic of UTP DWS such as moisture content, volatile matter, fixed carbon and ash are determined from its TG and dTG curves and tabulated in Table 1.

Table 1. Proximate Analysis Result.

\begin{tabular}{|c|c|}
\hline Physical characteristic & (weightage, \%) \\
\hline Moisture content (M) & 10.61 \\
\hline Volatile matter (VM) & 39.84 \\
\hline Fixed carbon (FC) & 18.61 \\
\hline $\operatorname{Ash}(\mathrm{A})$ & 30.94 \\
\hline
\end{tabular}


Citation: Suhaimi Hassan et al, 2019. Investigation on Combustion Characteristics of Malaysian Domestic Wastewater Sludge. Journal of Applied Sciences Research., 15(4): 1-7. DOI: 10.22587/jasr.2019.15.4.1

The physical characteristic of UTP DWS is compared with other wastewater sludge sample and selected biomass in Table 2. UTP DWS is compared against DWS sample from Poland [5], Kuala Lumpur, Malaysia [7, 8], Guangzhou, China [8], against selected biomass of ground coffee [8], poultry waste sludge (PWS) [10], and empty fruit bunch (EFP) of oil palm [11].

Table 2. Physical Characteristic Comparison of UTP DWS.

\begin{tabular}{|c|c|c|c|c|}
\hline \multirow{2}{*}{ Fuel Sources } & \multicolumn{4}{|c|}{ Characteristics (weightage, \%) } \\
\cline { 2 - 5 } & $\mathrm{M}$ & $\mathrm{VM}$ & $\mathrm{FC}$ & $\mathrm{A}$ \\
\hline UTP DWS & 10.61 & 39.84 & 18.61 & 30.94 \\
\hline Poland DWS [5] & 5.30 & 64.58 & 0.00 & 36.00 \\
\hline KL DWS (1) [6] & 12.00 & 48.90 & 19.00 & 32.00 \\
\hline KL DWS (2) [7] & 5.03 & 52.48 & 17.61 & 25.32 \\
\hline Guangzhou DWS [8] & 5.50 & 48.80 & 2.32 & 43.38 \\
\hline Ground coffee [8] & 2.69 & 74.82 & 21.93 & 0.56 \\
\hline PWS [10] & 6.90 & 63.00 & 9.49 & 21.08 \\
\hline EFB [12] & 0.00 & 77.10 & 16.80 & 6.10 \\
\hline
\end{tabular}

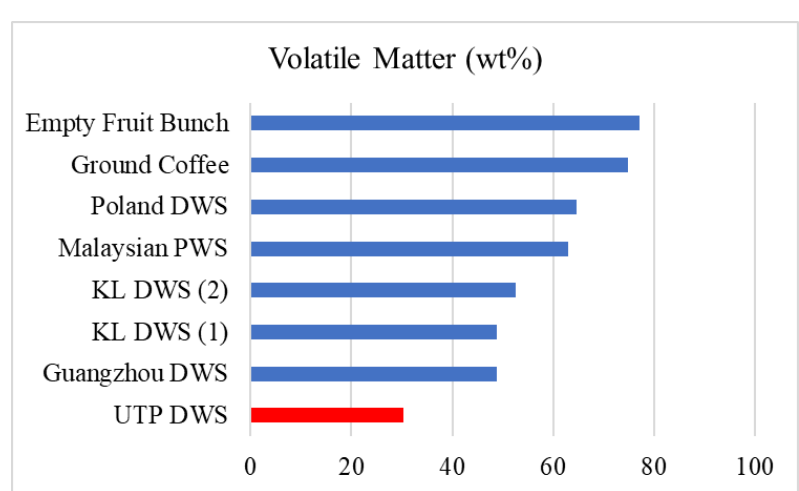

Figure 1. Fuel Sources Sorted According to Volatile Matter.

Between comparison of UTP DWS and other DWS and biomass in Figure 1, UTP DWS has the lowest volatile matter. Volatile matter plays a role in determining the amount of explosive combustible gas released when combusted while fixed carbon attributes to the amount of combustible carbon after devolatilisation process. Volatile thing is highly desirable in utilisation of biomass fuels as biomass with high volatile matter are commonly used to produce syngas in gasification of biomass fuels. Liberated explosive gases in devolatilisation process encourage the combustion of the sample. Therefore, the gases contributed largely in utilisation of biomass fuels.

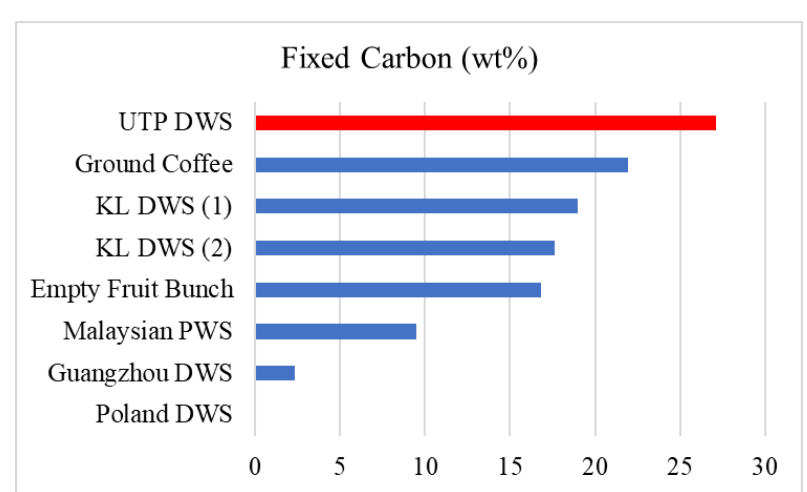

Figure 2. Fuel Sources Sorted According to Fixed Carbon.

UTP DWS has the highest fixed carbon when compared with other DWS and biomass in Figure 2. Fixed carbon is not highly sought after as much as volatile matter in biomass fuels.

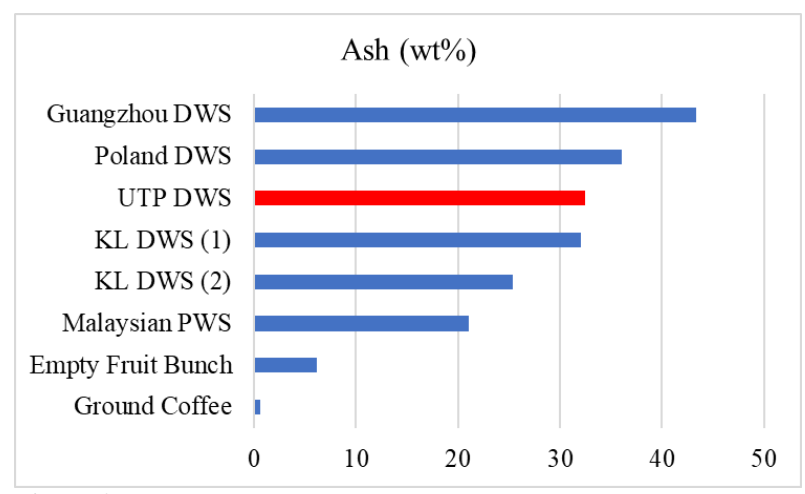

Figure 3. Fuel Sources Sorted According to Ash Content.

UTP DWS has above average ash content when compared with other DWS samples and biomass in Figure 3. High ash content is undesirable as ash is incombustible and it will promote the formation of slag in the furnace. 
Citation: Suhaimi Hassan et al, 2019. Investigation on Combustion Characteristics of Malaysian Domestic Wastewater Sludge. Journal of Applied Sciences Research., 15(4): 1-7. DOI: 10.22587/jasr.2019.15.4.1

In relation to the result obtained from proximate analysis on the sample, UTP DWS has comparable values with other DWS and biomass.

\subsection{Ultimate Analysis}

Chemical characteristic of UTP DWS such as carbon, hydrogen, nitrogen, sulphur and other (oxygen and ash content) weightage is determined as shown in Table 3.

Table 3. Ultimate Analysis Result.

\begin{tabular}{|c|c|}
\hline Chemical characteristic & (weightage, \%) \\
\hline Carbon $(\mathrm{C})$ & 36.06 \\
\hline Hydrogen $(\mathrm{H})$ & 5.28 \\
\hline Nitrogen $(\mathrm{N})$ & 10.48 \\
\hline Sulphur $(\mathrm{S})$ & 5.04 \\
\hline Other (oxygen and ash) & 43.14 \\
\hline
\end{tabular}

The chemical characteristic of UTP DWS is compared with other wastewater sludge sample and selected biomass in Table 4. UTP DWS is compared against DWS sample from Poland [5], Kuala Lumpur, Malaysia [7, 8], Guangzhou, China [8], against selected biomass of ground coffee [8], poultry waste sludge [10], and empty fruit bunch (EFP) of oil palm [12].

Table 4. Chemical Characteristic Comparison of UTP DWS.

\begin{tabular}{|c|c|c|c|c|}
\hline Fuel Sources & $\mathbf{C}(\boldsymbol{\%})$ & $\mathbf{H}(\boldsymbol{\%})$ & $\mathbf{N}(\boldsymbol{\%})$ & $\mathbf{S}(\boldsymbol{\%})$ \\
\hline UTP DWS & 36.06 & 5.28 & 10.48 & 5.04 \\
\hline Poland DWS [5] & 28.90 & 4.40 & 4.10 & 1.10 \\
\hline KL DWS (1) [6] & 33.00 & 5.00 & 6.00 & 1.20 \\
\hline KL DWS (2) [7] & 32.40 & 3.20 & 4.60 & 0.70 \\
\hline Guangzhou DWS [8] & 34.04 & 5.03 & 6.09 & 1.67 \\
\hline Ground coffee [8] & 56.94 & 15.23 & 2.76 & 0.98 \\
\hline PWS [10] & 52.78 & 8.87 & 5.52 & 0.80 \\
\hline EFB [12] & 47.65 & 5.20 & 1.82 & 0.36 \\
\hline
\end{tabular}

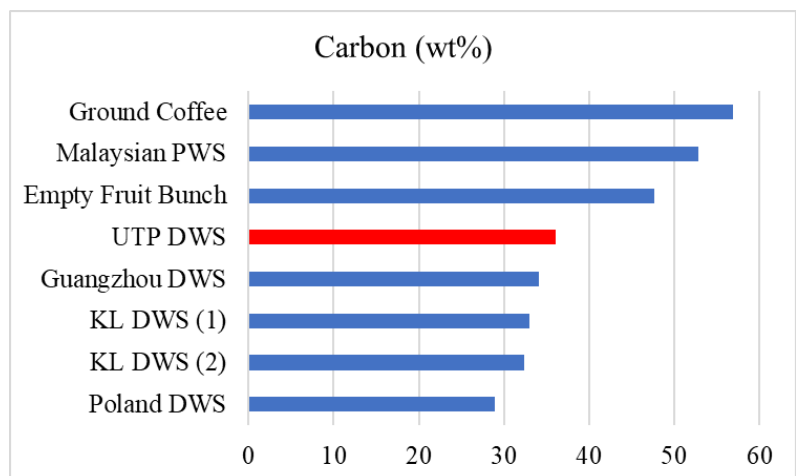

Figure 4. Fuel Sources Sorted According to Carbon Content.

UTP DWS has a relatively high amount of carbon among other DWS but lowers compared to other selected biomass as depicted in Figure 4. Carbon is an indicator for amount of combustible components in the sample such as volatile matter and fixed carbon.

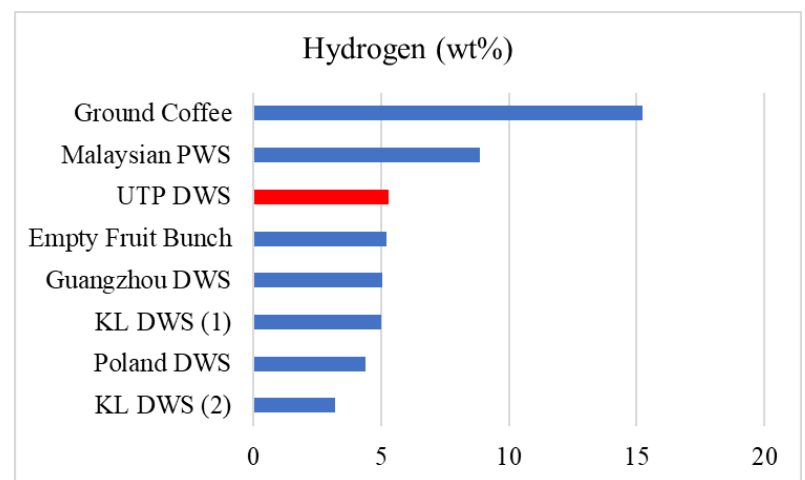

Figure 5. Fuel Sources Sorted According to Hydrogen Content.

Comparison in Figure 5 showed that UTP DWS has a relatively high amount of hydrogen among other DWS and comparable value with selected biomass except for ground coffee. Hydrogen in DWS could be extracted through syngas by gasification of the biomass [12]. 
Citation: Suhaimi Hassan et al, 2019. Investigation on Combustion Characteristics of Malaysian Domestic Wastewater Sludge. Journal of Applied Sciences Research., 15(4): 1-7. DOI: 10.22587/jasr.2019.15.4.1

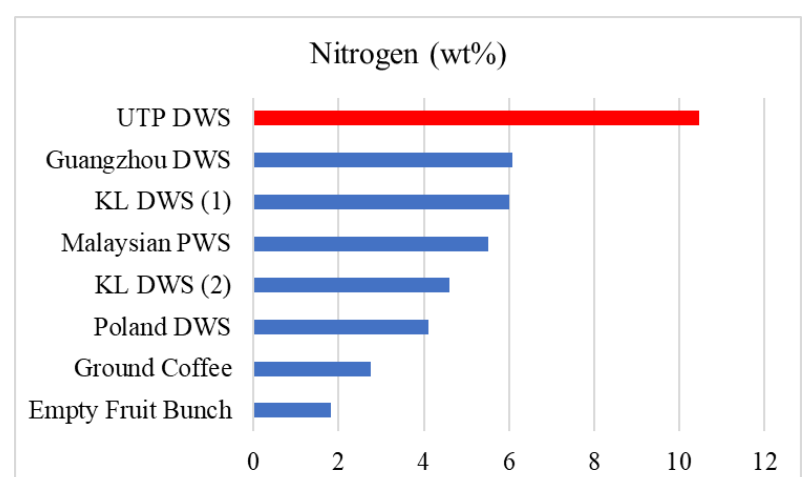

Figure 6. Fuel Sources Sorted According to Nitrogen Content.

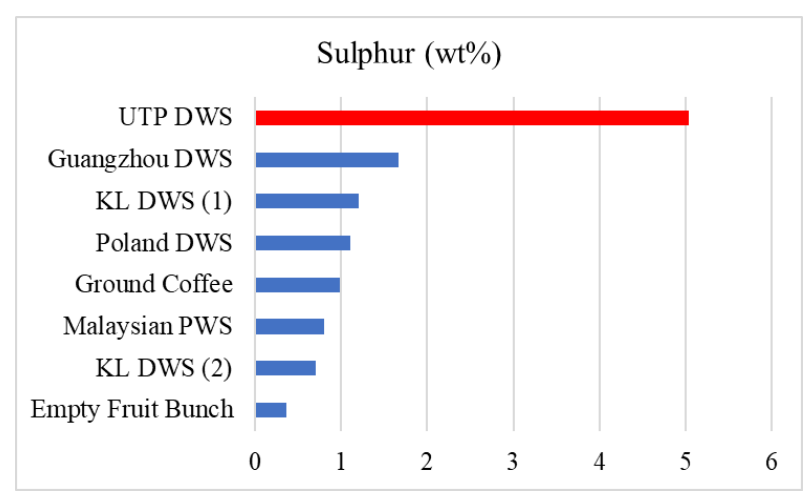

Figure 7. Fuel Sources Sorted According to Sulphur Content.

Comparison of nitrogen content and sulphur content was conducted between the fuel sources as shown in Figure 6. and Figure 7 respectively. UTP DWS has the highest amount of nitrogen and sulphur among other DWS and selected biomass. Nitrogen is associated with emission of NOx gases when combusted. The highly reactive gases are air pollutant and the emission are regulated through stringent legislation around the world. Sulphur is undesirable element in fuel source as it may evolve into harmful gases such as $\mathrm{SO}_{2}$ when combusted.

The high amount of nitrogen content maybe stems from high ammonia $\mathrm{NH}_{4}$ content from human waste. The high amount of sulphur may be related to the sources of influent of raw sewage. The raw sewage of UTP STP may contain a high amount of sulphuric acid from chemical lab waste, detergent waste, oil and grease from cafeteria.

Concerning the result obtained from the ultimate analysis on UTP DWS sample, the chemical characteristics of UTP DWS are comparable with exception to its sulphur content.

\subsection{Bomb Calorimetry}

The calorific values of UTP DWS is $13 \mathrm{MJ} / \mathrm{kg}$ and compared with other DWS and selected biomass in Table 5.

Table 5. Calorific Value Comparison of UTP DWS.

Table 5. Calorific Value Comparison of UTP DWS.
\begin{tabular}{|c|c|}
\hline Sample & CV $\mathbf{~ M J / k g )}$ \\
\hline UTP DWS & 13.00 \\
\hline Poland DWS [5] & 12.24 \\
\hline KL DWS (1) [6] & 15.60 \\
\hline KL DWS (2) [7] & 16.04 \\
\hline Guangzhou DWS [8] & 12.02 \\
\hline Ground coffee [8] & 21.30 \\
\hline PWS [10] & 24.60 \\
\hline EFB [12] & 16.80 \\
\hline
\end{tabular}

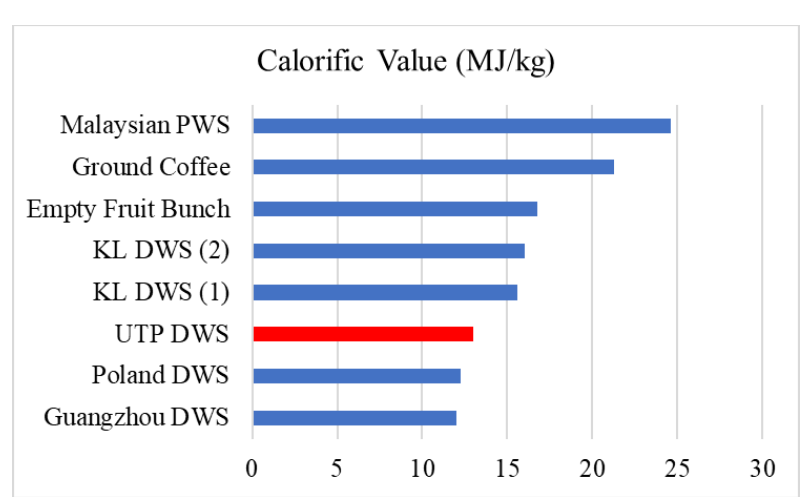

Figure 8. Fuel Sources Sorted According to Calorific Value. 
Citation: Suhaimi Hassan et al, 2019. Investigation on Combustion Characteristics of Malaysian Domestic Wastewater Sludge. Journal of Applied Sciences Research., 15(4): 1-7. DOI: 10.22587/jasr.2019.15.4.1

UTP DWS has average calorific value when compared with other DWS and lower when compared with other selected biomass. The position of UTP DWS among the compared fuel is illustrated in Figure 8. Among DWS, KL DWS (2) has maximum of $23 \%$ difference and Guangzhou DWS has minimum of $7.5 \%$ difference compared with UTP DWS.

With the result obtained from calorific value test on UTP DWS, its calorific value is comparable with other DWS. The calorific value is acceptable in comparison with other biomass as well.

\subsection{Thermogravimetric Analysis (TGA)}

Thermogravimetric analysis is conducted to study the thermal behaviour and TGA characteristic of UTP DWS from their TG and dTG curves produced by thermogravimetry analyser.

Figure 9 shows all selected TGA results of various heating rates and plotted on the same graph for side to side comparison. The TG and dTG curves depict various stages of combustion and the combustion profiles portray the combustibility of the biomass throughout the whole combustion process of UTP DWS.

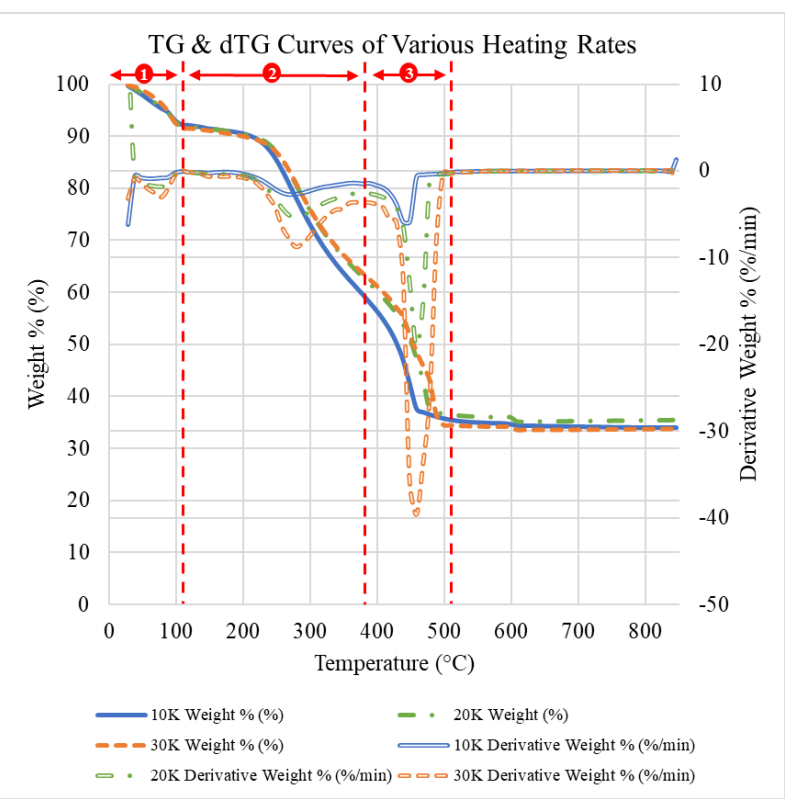

Figure 9. TG and dTG Curves of UTP DWS at Various Heating Rates.

The general combustion profiles of UTP DWS under oxidative atmosphere has 3 peaks observable in dTG curves, representing 3 different stages of thermal breakdown. The first peak occurred in step 1 between the temperature of $30^{\circ} \mathrm{C}$ to $110^{\circ} \mathrm{C}$, where the weight loss rate is the lowest for all 3 heating rates. The weight loss in stage 1 is largely contributed by evaporation of its moisture content and low boiling point organic matter. The second peak occurred in stage 2 between the temperature of $110^{\circ} \mathrm{C}$ to $380^{\circ} \mathrm{C}$, the weight loss of UTP DWS is due to the evolution of volatile matter or in another word, devolatilization process where complex organic structures are decomposed. The rate of weight loss in stage 2 is higher than stage 1 but lower than stage 3 . The third peak, the maximum combustion peak occurred in stage 3 between the temperature of $380^{\circ} \mathrm{C}$ to $520^{\circ} \mathrm{C}$. The weight of UTP DWS is decreasing at the highest rate in the stage due to oxidation of char particles where carbohydrates and lipids are decomposed. The high combustion reactivity of DWS char in stage 3 may be due to development of char porous structures [13]. The remaining weight is ash which is incombustible component of the combustion process. The combustion profiles and TGA characteristic of UTP DWS under various heating rates are tabulated in Table 6.

Table 6. TGA Characteristic of UTP DWS Under Various Heating Rates.

\begin{tabular}{|c|c|c|c|}
\hline \multicolumn{5}{|c|}{$10 \mathrm{~K} / \mathrm{min}$} & $20 \mathrm{~K} / \mathrm{min}$ & $30 \mathrm{~K} / \mathrm{min}$ \\
\hline \multicolumn{4}{|c|}{ Stage 1} \\
\hline $\mathrm{T}_{\text {peak }}\left({ }^{\circ} \mathrm{C}\right)$ & 58.05 & 81.54 & 77.55 \\
\hline $\mathrm{dTG}_{\text {max }}(\% / \mathrm{min})$ & -1.0135 & -2.1339 & -3.3106 \\
\hline $\mathrm{T}_{\text {range }}\left({ }^{\circ} \mathrm{C}\right)$ & $30-110$ & $30-110$ & $30-110$ \\
\hline \multicolumn{4}{|c|}{ Stage 2} \\
\hline $\mathrm{T}_{\text {ignition }}\left({ }^{\circ} \mathrm{C}\right)$ & 232.85 & 224.57 & 220.32 \\
\hline $\mathrm{T}_{\text {peak }}\left({ }^{\circ} \mathrm{C}\right)$ & 268.63 & 274.68 & 278.69 \\
\hline $\mathrm{dTG}_{\max }(\% / \mathrm{min})$ & -2.6803 & -5.6504 & -9.0996 \\
\hline $\mathrm{T}_{\text {range }}\left({ }^{\circ} \mathrm{C}\right)$ & $110-370$ & $110-380$ & $110-380$ \\
\hline \multicolumn{4}{|c|}{ Stage 3} \\
\hline $\mathrm{T}_{\text {peak }}\left({ }^{\circ} \mathrm{C}\right)$ & 445.30 & 460.24 & 454.51 \\
\hline $\mathrm{dTG}_{\text {max }}(\% / \mathrm{min})$ & -7.1479 & -25.4585 & -37.5599 \\
\hline $\mathrm{T}_{\text {range }}\left({ }^{\circ} \mathrm{C}\right)$ & $370-510$ & $380-510380-520$ \\
\hline $\mathrm{T}_{\text {burnout }}\left({ }^{\circ} \mathrm{C}\right)$ & 599.01 & 597.75 & 599.20 \\
\hline Burning time $(\min )^{7} 77$ & 40 & 29 \\
\hline
\end{tabular}

The performance index for combustion analysis are the ignition temperature $\left(\mathrm{T}_{\text {ignition }},{ }^{\circ} \mathrm{C}\right)$, peak temperature $\left(\mathrm{T}_{\text {peak }},{ }^{\circ} \mathrm{C}\right)$ and burnout temperature $\left(\mathrm{T}_{\text {burnout }},{ }^{\circ} \mathrm{C}\right)$ Ignition temperature is determined by the temperature where sudden weight loss occurred in dTG curve. Lower ignition temperature indicates ease of fuel to ignite. The ignition temperatures of UTP DWS are between $220^{\circ} \mathrm{C}$ to $230^{\circ} \mathrm{C}$ where the increasing heating rates decreases the ignition temperature but at low rate. Peak temperature is determined by the maximum rate of weight loss which corresponded with combustibility and reactivity of the fuel. The peak temperatures of UTP DWS are between $270^{\circ} \mathrm{C}$ to $280^{\circ} \mathrm{C}$ where the increasing heating rates increases the peak temperature but at a low rate. The burnout temperature is at temperature when there are no more weight loss and only ash remain. The burnout temperatures of UTP DWS are around $600^{\circ} \mathrm{C}$ where the increasing heating rates have no significant effect on burnout temperatures. The burnout temperature indicates the difficulty of complete combustion for the biomass. The burning time is the time taken for the combustion process up until burnout temperature. The burning time decreases significantly as the heating rate increases.

The combustion performance indicators are important as they directly correlate the residence time and furnace temperature of biomass fuel when combusted [14]. The TGA characteristic of UTP DWS indicates the biomass ignite at relatively low temperature and reaching peak reactivity at relatively low temperature in 
stage 2 which could be beneficial for the production of volatile gases through gasification. The higher heating rates could reduce the burning time, therefore, reducing the residence time inside the furnace.

The results for thermogravimetric analysis are comparable to TG data presented by Magdziarz and Werle [5] where their set-up is similar to the study conducted with different experimental parameters of $10 \mathrm{~K} / \mathrm{min}$ heating rate and $40 \mathrm{~mL} / \mathrm{min}$ synthetic air flowrate $\left(20 \% \mathrm{O}_{2}, 80 \% \mathrm{~N}_{2}\right)$.

\section{CONCLUSION}

From proximate analysis, the physical characteristic of UTP DWS has a moisture content of $10.61 \mathrm{wt} \%$, volatile matter of $39.84 \mathrm{wt} \%$, fixed carbon of 18.61 wt $\%$ and ash content of $30.94 \mathrm{wt} \%$. From ultimate analysis, the chemical characteristic of UTP DWS has carbon of $36.06 \mathrm{wt} \%$, hydrogen of $5.28 \mathrm{wt} \%$, nitrogen of $10.48 \mathrm{wt} \%$ and sulphur of $5.04 \mathrm{wt} \%$. UTP DWS has calorific value of $13 \mathrm{MJ} / \mathrm{kg}$.

The proximate analysis, ultimate analysis and calorific value test of UTP DWS provided supportive insights to when compared with other DWS, selected biomass and coal. The proximate analysis conducted suggested that the UTP DWS sample has the potential to be biomass fuel source, it has comparable physical characteristic among other DWS. The results of the ultimate analysis on UTP DWS exhibits the possibility of high pollutant gases such as NOx and SOx emission from combustion of DWS as it has high percentage of nitrogen and sulphur. The calorific value test of the studied sample shows that UTP DWS has comparable calorific value as other DWS. Based on the characteristic of UTP DWS and other selected DWS for comparison, DWS, in general, has potential to be biomass solid fuel but UTP DWS is not suitable due to its high nitrogen and sulphur content. The characteristic investigation does not paint the studied sample as outstanding fuel source but neither does it deny the UTP STP sludge sample as potential fuel source, therefore more in-depth studies are needed.

The combustion profiles and thermal behaviour of UTP DWS are investigated through thermogravimetric analysis at heating rates of $10 \mathrm{~K} / \mathrm{min}, 20 \mathrm{~K} / \mathrm{min}$ and $30 \mathrm{~K} / \mathrm{min}$. UTP DWS exhibit similar combustion process at comparable range throughout the various heating rates. In stage 1, the combustion of moisture and low boiling organic matter occurred at $30^{\circ} \mathrm{C}$ to $110^{\circ} \mathrm{C}$; in stage 2, the combustion of volatile matter occurred at $110^{\circ} \mathrm{C}$ to $380^{\circ} \mathrm{C}$; in stage 3 , the burning of fixed carbon occurred at $380^{\circ} \mathrm{C}$ to $520^{\circ} \mathrm{C}$. The reactivity of combustion processes, $\mathrm{dTG}_{\max }(\% / \mathrm{min})$ at each stage increased exponentially at increasing heating rates. UTP DWS generally ignites at a temperature ranging $220^{\circ} \mathrm{C}$ to $230^{\circ} \mathrm{C}$ and burnout at $600^{\circ} \mathrm{C}$. The burning time decreased significantly when heating rates increased. The root cause of high nitrogen and sulphur of UTP DWS could be investigated by identifying and analysing the content of raw sewage. Further investigation is required to confirm the potential of domestic wastewater sludge as potential fuel source.

\section{Authors' Contribution}

Ir. Dr. Suhaimi Hassan and Safuan Zakaria initiated, developed and conducted experimental work of this project while Michael Lo and M.Faizairi performed an analysis and discussion on the results and finally writing up the conference paper.

\section{Funding/Support}

The author would like to thanks to the Department of Mechanical Engineering, Department of Civil Engineering, and Centralised Analytical Laboratory of University of Technology PETRONAS for their support on this project under Final Year project scheme.

[1] IEA (International Energy Agency), "World Energy Outlook 2017," 2017

[2] Zaini Ujang and M. Henze, Municipal Wastewater Management in Developing Countries: IWA Publishing, 2006.

[3] WWAP (United Nations World Water Assessment Programme), "The United Nations World Water Development Report 2017. Wastewater: The Untapped Resource.," 2017.

[4] I. Shizas and M. Bagley David, "Experimental Determination of Energy Content of Unknown Organics in Municipal Wastewater Streams," Journal of Energy Engineering, vol. 130, pp. 45-53, 2004/08/01 2004.

[5] A. Magdziarz and S. Werle, "Analysis of the combustion and pyrolysis of dried sewage sludge by TGA and MS," Waste Management, vol. 34, pp. 174-179, 2014/01/01/ 2014.

[6] A. H. Abbas, A. B. A. Ibrahim, M. F. M. Nor, and M. S. Aris, "Characterization of Malaysian domestic sewage sludge for conversion into fuels for energy recovery plants," in 2011 National Postgraduate Conference, 2011, pp. 1-4.

[7] M. S. Zakaria, S. Hassan, and M. Faizairi, "Characterization of Malaysian Sewage Sludge Dried Using Thermal Dryer," Journal of Advanced Research in Fluid Mechanics and Thermal Sciences, vol. Vol. 5, pp. 24-29, 2015.

[8] J. Chen, J. Liu, Y. He, L. Huang, S. Sun, J. Sun, et al., "Investigation of co-combustion characteristics of sewage sludge and coffee grounds mixtures using thermogravimetric analysis coupled to artificial neural networks modeling," Bioresource Technology, vol. 225, pp. 234-245, 2017/02/01/ 2017.

[9] N. M. Mokhtar, R. Omar, M. A. M. Salleh, and A. Idris, "Characterization of Sludge from the Wastewater-treatment Plant of a Refinery," International Journal of Engineering and Technology, vol. 8, pp. 48-56, 2011.

[10] N. Aniza, S. Hassan, and M. Inayat, "Thermogravimetric kinetic analysis of Malaysian poultry processing waste material under inert and oxidative atmospheres.," Journal of Mechanical Engineering and Sciences (JMES), vol. 10, pp. 2289-4659, 2016.

[11] S. S. Idris, N. A. Rahman, and K. Ismail, "Combustion characteristics of Malaysian oil palm biomass, sub-bituminous coal and their respective blends via thermogravimetric analysis (TGA)," Bioresource Technology, vol. 123, pp. 581-591, 2012/11/01/ 2012.

[12] T. Glinwong and T. Wongchang, "Syngas production from biomass by linear heart gasifier," Energy Procedia, vol. 138, pp. 762-765, 2017/10/01/ 2017.

[13] S. Deng, H. Tan, X. Wang, F. Yang, R. Cao, Z. Wang, et al., "Investigation on the fast co-pyrolysis of sewage sludge with biomass and the combustion reactivity of residual char," Bioresource Technology, vol. 239, pp. 302-310, 2017/09/01/ 2017.

[14] T. Miranda, A. Esteban, S. Rojas, I. Montero, and A. Ruiz, "Combustion Analysis of Different Olive Residues," International Journal of Molecular Sciences, vol. 9 , pp. 512-525, 04/04 